\title{
TRANSLATORS VS TRANSLATRESSES' STRATEGIES: ETHICAL AND IDEOLOGICAL CHALLENGES
}

\author{
Vanessa Leonardi ${ }^{1}$ \\ University of Ferrara (Italy) \\ Annarita Taronna ${ }^{2}$ \\ University of Bari (Italy)
}

\begin{abstract}
In the last few years there has been an increasing interest in the issue of gender in translation practice especially thanks to the work of feminist critics and translators who see the act of translating as an activity which involves making use not of speciously neutral, so-called objective strategies, but rather dynamic procedures and tactics which negotiate and are negotiable, open and contingent, and which never assume feminine subjectivity to be an absolute and stable category. Drawing on such premises, this work will focus on the interrelation between identity, textuality and translation in an attempt to explore the idea that gender representation in translation practice may be shaped by the translator's identity and this can be partly detected through their strategies. Specifically, we will show the role these factors play through the analysis of two case-studies, that is 1) the feminist (unpublished) translation of Mark Haddon's The Curious Incident of the Dog in the Night-Time by María Reimóndez and its final (published) translation into Galician with additional comparisons in Spanish and Italian, and 2) the two Italian translations of Woolf's Orlando (1928), carried out respectively by a woman and then by a man. In both cases, translation
\end{abstract}

1. Vanessa Leonardi wishes to thank the Ministerio de Ciencia e Innovación (grant research FEM2009-10976) for the financial support for this research.

2. Leonardi worked on the analysis of Haddon's The Curious Incident of the Dog in the Night-Time whereas Taronna worked on the analysis of Woolf's Orlando. Furthermore, Taronna's analysis was partly published in Pratiche traduttive e Gender Studies, Roma: Aracne, 2006. 
strategies will be discussed in an attempt to unveil the ideological reading of translation and to raise translators' awareness of gender constructs in textuality.

\section{Resumen}

En los últimos años se ha visto incrementado el interés por el tema del género en la práctica de la traducción. Ello se debe a la intensa labor de críticos feministas y traductores que conciben el acto de traducción como una actividad que no implica el uso de estrategias aparentemente neutrales y comúnmente definidas objetivas, sino que emplea tácticas y procedimientos bastante dinámicos que negocian y son negociables, abiertos, contingentes; además, opinan que la sujetividad femenina no pueda considerarse una categoría estable y absoluta. Basándose en estas premisas, este trabajo enfocará la interrelación entre identidad, textualidad y traducción a fin de intentar explorar la idea de que la representación del género en la práctica de la traducción puede ser determinada por la identidad del traductor y que ésta puede a su vez detectarse parcialmente a partir de sus estrategias. Se hará específicamente hincapié en el papel desempeñado por estos factores a partir del análisis de dos casos de estudio, es decir 1) la traducción feminista (inédita) de la obra de Mark Haddon The Curious Incident of the Dog in the Night-Time, realizada por María Reimóndez, y la traducción final al gallego (publicada) con comparaciones adicionales en español e italiano; 2) las dos traducciones al italiano de la novela de Woolf Orlando (1928), realizadas respectivamente por una mujer y un hombre. En ambos casos se discutirán las estrategias de traducción con vistas a desvelar la lectura ideológica de la traducción y aumentar la conciencia de los traductores respecto a los constructos de género en la textualidad.

Keywords: Translation. Gender. Ideology. Identity. Translation strategies.

Palabras clave: Traducción. Género. Ideología. Identidad. Estrategias de traducción. 


\section{Introduction}

The notion of translation strategies plays a crucial role in the field of Translation Studies since they link theory and practice together as also acknowledged by Hönig and Kussmaul (1982). Translation strategies can help translators solve equivalence problems and, at the same time, they offer them an opportunity to reflect upon the impact and implications of their choices. Within the field of Translation Studies a great deal of interest has been devoted to the so-called "feminist translation strategies" as if they were a different set of strategies. This paper, however, argues that feminist translation strategies are not specifically "feminist" as they resemble ordinary translation strategies. Male translators might also be motivated by ideological factors in their strategies and, as a result, they may be more or less visible in their translation. It is therefore our intention to show a few examples of translation strategies adopted by men and female translators from a comparative and contrastive perspective in order to discuss both the implications as well as the (in)visibility of these translators and their strategies in their work. Developing out of our interest in feminist explorations of gender as a cultural construct and in translation as a cultural transfer, this work will focus on two specific casestudies, such as: 1) the feminist (unpublished) translation of Mark Haddon's The Curious Incident of the Dog in the Night-Time by María Reimóndez and its final (published) translation into Galician with additional comparisons in Spanish and Italian, and 2) the two Italian translations of Woolf's Orlando (1928), carried out respectively by a woman and then by a man. Translation strategies will be discussed in an attempt to bridge the gap between ethics and ideology as well as between theory and practice.

\section{Translation as a cultural and gendered practice}

Within the cultural studies approach to translation, the issues of gender as cultural construct and translation as a cultural transfer emerge, shedding light on feminist approaches to Translation Studies. In this context, Luise von Flotow's article "Dis-unity and Diversity: Feminist approaches to Translation Studies" (1998: 23) is a key-text that details the impressive growth in recent 
years of feminist scholarship in the area of Translation Studies. Von Flotow charts the lines of antagonisms and tensions that separate the different feminist theoreticians, particularly focusing on questions of identity politics, positionality and historical dimension. We draw on these theoretical premises to examine the interrelation between identity, textuality and translation in an attempt to explore the idea that gender representation in translation practice may be shaped by the identity of the translator. Crucially, it is important here to show the role these factors play because they have guided the analysis of the two case-studies above mentioned.

Firstly, the historical dimension cannot make gendered subjectivity change with times and with the political and institutional constellations that determine concrete options, real possibilities or real obstacles. It means that the translator's perceptions and interests change with time as does identity. Secondly, identity politics concern the sense of agency in translation that must be understood in relation to the various sites through which the translating subject defines himself/herself. The translator's identity, as well as the writer/critic's identity, has an effect on his/her translation practice because it may incorporate certain consciously identifiable cultural/political characteristics that will determine his/her insights, opinions and prejudices. Thirdly, the concept of positionality can be used in Translation Studies as a fluid location from which to construct meaning, as a perspective from which values are interpreted and constructed differently and at different times under the influence of institutional, economic, cultural and other factors. The combination of these three factors introduces the issue of gender awareness in translation practice which implies that the translator's "responsibility" should not be limited to a mere (re)writing of the source text. Translators, indeed, need to implicate themselves, to abandon the pretence of objective distance and to make plain their theoretical positions and practical decisions regarding the text. Feminist critics and translators support the rethinking and subversion of hierarchical paradigms in Translation Studies. Crucially, they see the act of translating from a gender-oriented perspective, as an activity which involves making use not of speciously neutral, so-called objective strategies, but rather dynamic procedures and tactics which negotiate and are negotiable, open and contingent and which never assume feminine subjectivity to be an absolute and stable category.

The feminist theoretical background supporting the rethinking and the subversion of hierarchical paradigms in translation theory and practice draws on post-structuralist and deconstructionist discourses of the last twenty years. In particular, it is through Derrida and Foucault that feminist translation finds 
its new definitions of textual authority and develops its politics of transmission. Another result of the great influence of deconstruction and post-structuralism affecting both gender and Translation Studies is the interdependence between the translator's identity and textuality. This interdependence makes translation a negotiable practice on which we can (re)conduct our own reading. Translation gives us a sense of immersion and identification and helps us get inside textuality as translators, amateurs and literary critics. This can be done either directly by translating the literature we are studying or indirectly by comparing and revising translations - as we are going to do with the abovementioned case-studies.

\section{Translation strategies: Female, male or neutral translation strategies?}

Any act of translation implies choices, decisions and strategies on the behalf of translators in order to deal with linguistic and extra-linguistic features or cases of non-equivalence of the text they work on. Broadly speaking, strategies are used by translators when they encounter a problem as they should be able to determine what to include and what to exclude and be able to foresee the implications of their choices. These choices and strategies tend to find a useful collocation or justification in translation theory.

Throughout the years, the phenomenon of "translation strategies" has been extensively discussed and several translation scholars and professional translators have proposed different approaches, methods and models to justify these strategies in translation. For the purposes of this article, translation strategies are defined according to Chesterman's description provided in his work Memes of Translation published in 1997. In line with his description, translation strategies are thought: 1) to apply to a process, 2) to involve text manipulation, 3) to be goal-oriented, 4) to be problem-centred, 5) to be potentially conscious and finally 6) to be intersubjective in that they can be understood by other people beside the one who uses them in the first place.

This work also takes into account other classifications of translation strategies which have been mainly applied to the context of feminist studies and, more precisely, Feminist Translation Studies but, in our opinion, they could easily apply to both male and female translators who are not associated with any declared feminist practice. In 1991 Von Flotow identified three main feminist strategies: 1) Supplementing, 2) Prefacing and Footnoting and 3) Hijacking. However, if we take a closer look, we will see that these strategies are not feminist but rather it is the way feminist translators use them that can be associated with a feminist practice. Through these strategies, she has not only helped feminist translators, among the others, try to make their position, 
ideology and interpretation as visible as possible, but she has not allowed gender issues to be cast into oblivion within the academic field of Translation Studies. Taking into account the proliferation of feminist translations and translations of feminist texts and the work done by feminist translation researchers, von Flotow has confirmed (Brufau Alvira 2010: 284) that the above mentioned strategies are still useful though they need to be constantly reconsidered, adjusted and adapted to the different contexts in what she calls "highjacking into context" (von Flotow in Brufau Alvira 2010: 284). Even more important than the translation strategies, however, she recognizes that only thanks to the continuous work of translation criticism, readers, teachers, journalists and others who devote their time, energy or knowledge to compare two texts in detail, we can know about the influence translators can exert on a text and how to overcome any kind of essentialism based on a mere generalization about "men" or "women".

The same applies to Massardier-Kenney's (1997) classification of translation strategies which can easily fit the feminist agenda. She divides them into two main groups: 1) author's centred (recovery, commentary, resistance and thick translation) and translator's centred strategies (commentary, use of parallel texts and collaboration). Both groups are particularly useful within a feminist framework because they highlight the importance of women as producers of texts, be it as authors or translators. Indeed, whether a feminist approach in translation relies on author-centred or translator-centred strategies in order to bring out the importance of the feminine for the formation of texts, it leads us to reconsider the object of translation not as a text to serve or to master, but as a cultural event to "re-present". The feminist recognition that this re-presentation involves an elusive notion of the feminine means that we need to examine the various ways in which gender is connected to or disconnected from the texts, and the way it relates to the specific mode of representation claimed by feminist translators.

Such feminist approaches to translation can be conceived as acts of intercultural ideological re-mediation (Guarrido 2005) within the framework offered by second and third wave feminist linguistics (Mills 2003 and 2008). Therefore, it is likely that feminist approaches to translation - especially those focusing on the translator changing language and adapting or manipulating texts- lie somewhere between the two waves and maintain the contact between them. Nevertheless, this study argues that these "feminist translation strategies" are not necessarily "feminist" as they can be detected in both male and female non-feminist translators' work as a way, to a certain extent, to mark their visibility and hence their ideology in their work. 
In order to narrow down our comparative research on translation strategies, focus will be particularly laid upon the translation of gender from English into Galician, Spanish and Italian in the first case study, whereas in the second case, emphasis is placed upon the lexical choices adopted by the female and the male translators.

The translation of the grammatical or natural gender may have several implications in terms of ethics and ideology. When dealing with the translation of natural-gender words, there is a need to determine whether they specifically refer to women, men or both. For instance, the word readers in Italian could be both masculine or feminine. If the sex is not clearly stated, then it is grammatically correct to use the masculine "all-inclusive" form. These considerations lead to ethical debates on the most politically-correct gender forms to employ. If shifts from the standard norms are made, then they are thought to have an ideological slant, especially in the case of translations carried out by women. This "male-as-norm" principle, as also acknowledged by Braun (1997), seems to be universally accepted and any deviation from this norm tends to be heavily criticised and attacked under the label of "feminist use" of language.

The translation of lexical items can also contribute to unveil the ideological character of translations in so far as they are not only a mere means of rendering a direct equivalent in the target language, but also a means of manipulation motivated by the translator's choices. For example, investigating dis/similarities, semantic deviations and equivalences emerging from the translations of specific keywords revealing the representation of gender in translation and the textual sites of ideological tension where questions about the nature and representation of femininity + masculinity (= androgyny) are at stake can help us realize that the presence of a particular word in a particular context is never innocuous, but there is always some concealed "idea(l)" behind it. This worked to the advantage of feminists who used their translated versions as weapons against society whose interest went beyond the actual status of women.

\section{Ideological reading (and translation) of gender: Moisés Barcia vs María Reimóndez}

The curious idea of writing this analysis was conceived further to a curious incident regarding a curious article written by a Galician feminist translator whose curious translation was not published for several curious reasons. The translator in question is María Reimóndez, who back in 2004 was commissioned the translation of Mark Haddon's The Curious Incident of the Dog in 
the Night-Time into Galician. Haddon's work won the Whitbread Book of the Year in 2003 and has been translated into more than 40 languages, including Galician. Problems began to arise when in 2007 she handed in her first draft to the publisher who, in the meantime, was a different one from the original. Reimóndez, indeed, was initially hired by Edicións Xerais although the translation rights were eventually bought by Rinoceronte Editora. The translator was surprised to see so many corrections on her version and claimed:

When I received the first corrections I was stunned by the level of irrelevant intervention and change introduced into the text: changes involving, for instance, the substitution of certain words with their absolute synonyms in Galician, such as 'colexio' and 'escola', both meaning 'school'. I decided not to comment on any of these; however, I did comment on some amendments that concerned my use of feminist translation strategies. In some cases my text had been masculinized. (2009: 9)

On the one hand, María Reimóndez clearly admitted refusing to hand in a sexist translation favouring the use of the masculine gender over the feminine in cases where English uses a neutral form. On the other hand, however, the publisher, Moisés Barcia, accused her of systematically changing neutral words for feminine ones, thus introducing a bias into the work by taking out references to male characters, even when the gender was clear. In this respect Barcia claimed that "As we corrected her text, we realised that she was systematically translating neutral words into feminine ones, and masculine words into feminine or neutral forms [...] She chose to make the narrator's pet rat a female, even though its name was Toby" (The Telegraph, $5^{\text {th }}$ April 2008). Reimóndez defended herself by claiming that "The translation strategies I use include not using the masculine form systematically" (ibid.); nevertheless, the publisher opted for re-translating the book himself and publishing it as $O$ curioso incidente do can á media noite. In this respect, Castro (2009) acknowledges that in her translation Reimóndez decided to apply the so-called "ethics of location" elaborated by Venuti (1998) in order to assess each single case of gender instead of opting for a systematic use of gender as requested in the editorial guidelines.

This "curious incident" therefore regarded the use of feminist strategies by Reimóndez which "implied not translating gender neutral nouns in English into masculine or feminine according to patriarchal expectations" (Reimóndez 2009: 68) and it does bring problems related to the translation of gender to light. The problem is particularly encountered when translating works from English (characterised by natural gender) into those languages which are characterised by grammatical gender, such as Italian, Spanish and Galician. 
The following analysis is based on a comparison between the unpublished feminist version and the official published version in Galician ${ }^{3}$ but, at the same time, some references will also be made to the Spanish and Italian versions in order to have a larger comparative framework. It is worth noting, at this stage, that except from the published Galician translation, all the other versions were translated by female translators.

\section{Practical Analysis}

Strategy n. 1 = Disambiguating gender-inclusive cases in English and choosing a grammatical gender in Galician (Accepted Cases)

\begin{tabular}{|l|l|l|l|l|}
\hline \multicolumn{1}{|c|}{ ST } & \multicolumn{1}{c|}{ MR } & \multicolumn{1}{c|}{ TT (Galician) } & \multicolumn{1}{c|}{ SP } & \multicolumn{1}{c|}{ IT } \\
\hline $\begin{array}{l}\text { The sergeant } \\
\text { behind the } \\
\text { desk had very } \\
\text { hairy hands } \\
\text { and he had } \\
\text { bitten his nails } \\
\text { [... }\end{array}$ & O sarxento $(16)$ & $\begin{array}{l}\text { O sarxento } \\
(27)\end{array}$ & $\begin{array}{l}\text { El sargento } \\
(14)\end{array}$ & $\begin{array}{l}\text { Il sergente } \\
(18)\end{array}$ \\
\hline
\end{tabular}

In this example, it is quite easy to disambiguate the sex of the sergeant as there are clear references, such as 'he' and 'his'. The same pattern is observed in all the target texts (TTs) analysed where the male gender has been faithfully reproduced.

\begin{tabular}{|l|l|l|l|l|}
\hline \multicolumn{1}{|c|}{ ST } & \multicolumn{1}{c|}{ MR } & TT (Galician) & \multicolumn{1}{c|}{ SP } & \multicolumn{1}{c|}{ IT } \\
\hline $\begin{array}{l}\text { Eventually } \\
\text { scientists } \\
\text { will discover } \\
\text { something that } \\
\text { explains ghosts } \\
\text { [...] (125) }\end{array}$ & os científicos & $\begin{array}{l}\text { OS científicos } \\
(140)\end{array}$ & $\begin{array}{l}\text { Los científicos } \\
(88)\end{array}$ & $\begin{array}{l}\text { gli scienziati } \\
(120)\end{array}$ \\
\hline
\end{tabular}

The use of the term "scientists" in the ST is clearly aimed at addressing both women and men. This gender-inclusive term is faithfully reproduced in the various TTs analysed. It is worth noting, however, that despite being a declared feminist translator Reimóndez did not opt for a gender-neutral term in this example as one would have expected to occur. One of the main proposals

3. Some of the examples used in this analysis were partly taken from Castro's (2009) work quoted in the bibliographical references, whereas others were kindly provided by Olga Castro herself through email exchanges with Vanessa Leonardi. 
put forward by language reformers in this respect regards the possibility to alter the gender reference especially in cases where it is meant to include both sexes. As Leonardi (2007: 98) rightly acknowledged "Feminist criticism aimed at providing recommendations for neutralizing gender distinctions in language in order to promote political correctness". Feminist reformers would have therefore opted for either a gender-neutral term or, from a more radical feminist perspective, for a feminine term. None of these two options were adopted by Reimóndez, who remained faithful to the male-as-norm principle.

\begin{tabular}{|l|l|l|l|l|}
\hline \multicolumn{1}{|c|}{ ST } & \multicolumn{1}{c|}{ MR } & \multicolumn{1}{c|}{ TT (Galician) } & \multicolumn{1}{c|}{ SP } & \multicolumn{1}{c|}{ IT } \\
\hline $\begin{array}{l}\text { some of the } \\
\text { children at } \\
\text { school are } \\
\text { horrible to } \\
\text { animals (126) }\end{array}$ & algúns nenos & $\begin{array}{l}\text { algúns nenos } \\
(140)\end{array}$ & $\begin{array}{l}\text { algunos de los } \\
\text { niños (88) }\end{array}$ & $\begin{array}{l}\text { alcuni di noi } \\
(121)\end{array}$ \\
\hline
\end{tabular}

The same argument applies in this case where "children" is a gender-inclusive term aimed at addressing both sexes. It is interesting to note, however, how the Italian version differs from both the ST and the other TTs. In terms of translation strategy, the Italian version does not seem to comply with the original text where the protagonist clearly likes animals and would never hurt them; this is why he is detached from "those children" who do hurt animals. The choice of using alcuni di noi (some of us) in the Italian version, however, includes him within that group of children. Although this strategy does not imply any gender specificity, it can be regarded as a different interpretation of the ST. Does this strategy make the female Italian translator become a feminist? It is clear that not all forms of non-conformity or deviation from the original text on the behalf of female translators are always cases of feminist strategies.

\begin{tabular}{|c|c|c|c|c|}
\hline ST & MR & TT (Galician) & SP & IT \\
\hline $\begin{array}{l}\text { And the man } \\
\text { who had shoes } \\
\text { that did not } \\
\text { match stood } \\
\text { in front of me } \\
\text { and said, "Big } \\
\text { cheese. Oh yes. } \\
\text { The nurses. } \\
\text { (230) }\end{array}$ & Enfermeiras & $\begin{array}{l}\text { Enfermeiras } \\
\text { (242) }\end{array}$ & $\begin{array}{l}\text { Las } \\
\text { enfermeras } \\
(157)\end{array}$ & $\begin{array}{l}\text { Le infermiere } \\
\text { (213) }\end{array}$ \\
\hline
\end{tabular}


Finally, it is interesting to note how all the translators of the various TTs analysed opted for a feminine gender in translating the term "nurses" from English. It is worth mentioning, in this respect, that no indication as to whether it refers to women, men or both is given in the ST. From a stereotypical perspective, however, this term seems to be one of the professions which are most commonly associated with women. Doctors are usually associated with men, secretaries are women, whereas fire fighters are men. This stereotypical pattern seems to be confirmed by the translators' strategy to opt for a feminine form.

Strategy $n .1$ = Disambiguating gender-inclusive cases in English and choosing a grammatical gender in Galician (Non-Accepted Cases)

\begin{tabular}{|l|l|l|l|l|}
\hline \multicolumn{1}{|c|}{ ST } & \multicolumn{1}{c|}{ MR } & TT (Galician) & \multicolumn{1}{c|}{ SP } & \multicolumn{1}{c|}{ IT } \\
\hline $\begin{array}{l}\text { Then Mrs. } \\
\text { Shears came } \\
\text { over [...] she } \\
\text { was wearing } \\
\text { sandals and } \\
\text { jeans and a } \\
\text { T-shirt which } \\
\text { had the words } \\
\text { WINDSURF } \\
\text { and CORFU } \\
\text { and a picture } \\
\text { of a windsurfer } \\
\text { on it. (37) }\end{array}$ & & $\begin{array}{l}\text { un } \\
\text { windsurfista } \\
(49)\end{array}$ & $\begin{array}{l}\text { un } \\
\text { windsurfista } \\
(28)\end{array}$ & $\begin{array}{l}\text { Un tizio sul } \\
\text { windsurf (39) }\end{array}$ \\
\hline
\end{tabular}

This example is one of the most unacceptable corrections made on Reimóndez's version according to her own words (2009: 76-77). If we take a look at the context, it seems to be more appropriate to translate this term in the masculine form as a gender-inclusive term since no indication about the windsurfer's sex is given. It is likely, however, that Reimóndez translated it into the feminine as the T-shirt mentioned in the text is worn by a woman. Is this a valid justification for her strategy? It may be a valid justification based on her interpretation of the text and her willingness to use a non-sexist language as reiterated in her article where she claims that: "Any translation is an interpretation of the text, and therefore the author has no right to decide over that new text" (ibid.: 83). Her statement clearly implies the fact that the only person able to decide upon the new text is the translator him/herself. This is perfectly exemplified in her strategy to opt for a feminine form. 


\begin{tabular}{|l|l|l|l|l|}
\hline \multicolumn{1}{|c|}{ ST } & \multicolumn{1}{c|}{ MR } & \multicolumn{1}{c|}{ TT (Galician) } & \multicolumn{1}{c|}{ SP } & \multicolumn{1}{c|}{ IT } \\
\hline $\begin{array}{l}\text { I had to go to } \\
\text { the dentist } \\
(140)\end{array}$ & a dentista & $\begin{array}{l}\text { un dentista } \\
(153)\end{array}$ & $\begin{array}{l}\text { al dentista } \\
\text { (96) }\end{array}$ & $\begin{array}{l}\text { Dal dentista } \\
\text { (133) }\end{array}$ \\
$\begin{array}{l}\text { (feminine) } \\
\text { (masculine) }\end{array}$ & $\begin{array}{l}\text { un = A } \\
\text { (masculine) } \\
\text { unha }=\mathrm{A} \\
\text { (feminine) }\end{array}$ & & \\
\hline
\end{tabular}

In line with Reimóndez's view, this strategy of hers clearly reflects her decision to use non-sexist language in the text in cases where no clear indication of the sex is given. As a feminist translator, she believes that language and texts do not have to comply with the male-as-norm principle and if a masculine word can be used as a gender-inclusive term, why should not a feminine term? Nevertheless, there does not seem to be coherence with her previous strategies, in particular the one mentioned above in translating the English term scientists as cientificos (the masculine form in line with the male-as-norm principle).

\begin{tabular}{|l|l|l|l|l|}
\hline \multicolumn{1}{|c|}{ ST } & \multicolumn{1}{c|}{ MR } & TT (Galician) & \multicolumn{1}{c|}{ SP } & \multicolumn{1}{c|}{ IT } \\
\hline $\begin{array}{l}\text {.. someone I } \\
\text { knew, like a } \\
\text { teacher from } \\
\text { school (196) }\end{array}$ & $\begin{array}{l}\text { unha mestra } \\
\text { da escola }\end{array}$ & $\begin{array}{l}\text { profesor do } \\
\text { colexio (209) }\end{array}$ & $\begin{array}{l}\text { un profesor del } \\
\text { colegio (133) }\end{array}$ & $\begin{array}{l}\text { un insegnante } \\
(182)\end{array}$ \\
\hline
\end{tabular}

This example is another case of non-sexist language use where preference is given to a feminine noun. Except from Reimóndez, all the other translators opted for a masculine term.

However, as the gender of this noun is not marked in the ST and in order to avoid typical stereotypical associations of women being teachers, it could have been probably a better strategy to use a more neutral term, such as "someone who teaches in school". 


\begin{tabular}{|l|l|l|l|l|}
\hline \multicolumn{1}{|c|}{ ST } & \multicolumn{1}{c|}{ MR } & \multicolumn{1}{c|}{ TT (Galician) } & \multicolumn{1}{c|}{ SP } & \multicolumn{1}{c|}{ IT } \\
\hline $\begin{array}{l}\text { And the man } \\
\text { who had shoes } \\
\text { that did not } \\
\text { match stood } \\
\text { in front of me } \\
\text { and said, "Big } \\
\text { cheese. Oh yes. }\end{array}$ & Maldito & $\begin{array}{l}\text { Condenada } \\
\text { mentireiro }\end{array}$ & $\begin{array}{l}\text { Maldita } \\
\text { mentirosa } \\
\text { The Nurses. }\end{array}$ & $\begin{array}{l}\text { Maledetto } \\
\text { bugiardo (213) }\end{array}$ \\
$\begin{array}{l}\text { Never. Bloody } \\
\text { liar. (230) }\end{array}$ & & & & \\
\hline
\end{tabular}

This example is surprising in that it is the male translator's strategy which clearly shows a certain degree of ideological mediation and sexism. In the ST, indeed, there is not enough context to determine the liar's sex and therefore it seems to be more appropriate to opt for a masculine, gender-inclusive term. It is interesting to note that the Galician version opts for the use of a feminine gender because in Barcia's opinion the word clearly "referred to the man's wife" (Reimóndez 2009: 81), although this does not seem to be the case as also acknowledged by Reimóndez herself. If a female translator had deliberately changed the grammatical gender in such a way, she would have been immediately labelled "feminist" and criticised for her strategy. The question, however, is that in this case it is a man who did it, and his choice does not seem to be subject to any form of objection or criticism. Can Barcia's translation strategy be justified by any theoretical approach? Is not this the same case as the one cited earlier where Reimóndez decided to turn the windsurfer into a female windsurfer? In both cases, the translators justified their strategy on the basis of their interpretation and understanding of the ST. Furthermore, in both cases there is no a clear indication as to whether such a grammatical gender should be a feminine or a masculine form.

Strategy n. $2=$ Using a neutral term in Galician as it is English (Non-Accepted Cases)

Neuter in ST

\begin{tabular}{|l|l|l|l|l|}
\hline \multicolumn{1}{|c|}{ ST } & \multicolumn{1}{c|}{ MR } & TT (Galician) & \multicolumn{1}{c|}{ SP } & \multicolumn{1}{c|}{ IT } \\
\hline $\begin{array}{l}\text { Then the } \\
\text { police arrived. } \\
\text { I like the } \\
\text { police (7) }\end{array}$ & a policía & os policías & $\begin{array}{l}\text { Entonces llegó } \\
\text { la policía. A mí } \\
\text { me gustan los } \\
\text { policías. }\end{array}$ & \\
\hline
\end{tabular}


In this example, Reimóndez's version seems to comply with the neutral form used in the ST whereas Barcia's version marks the masculine gender. Can we consider it a case of sexism in language? Perhaps, Reimóndez's strategy was wrongly interpreted by Barcia and this is due to the fact that in Galician "a policía" could be translated as both 'the policewoman' and 'the police' as abstract noun. Based upon this explanation, Reimóndez's strategy could seem to be ambiguous and left open to interpretation, whereas the result of Barcia's strategy could seem to be sexist and more ideologically slanted.

Marked gender in ST

\begin{tabular}{|c|c|c|c|c|}
\hline ST & MR & TT (Galician) & SP & IT \\
\hline $\begin{array}{l}\text { There was a } \\
\text { policewoman } \\
\text { and a } \\
\text { policeman (7) }\end{array}$ & $\begin{array}{l}\text { unha muller } \\
\text { policía e un } \\
\text { home policía }\end{array}$ & $\begin{array}{l}\text { unha policía e } \\
\text { un policía }\end{array}$ & $\begin{array}{l}\text { una policía y } \\
\text { un policía. La } \\
\text { mujer policía } \\
\text { tenía [...]. El } \\
\text { policía llevaba } \\
{[\ldots . .] \text { (8) }}\end{array}$ & $\begin{array}{l}\text { una donna } \\
\text { poliziotto e un } \\
\text { poliziotto (10) }\end{array}$ \\
\hline
\end{tabular}

In this example, the gender is marked in the ST and the same is done in the various TTs analysed but in different ways. Barcia's version seems to reproduce faithfully the ST whereas Reimóndez's translation is slightly more marked as it occurs in the Italian version. Since the grammatical gender in Galician and Italian can be easily marked by different endings or articles and other determiners, there is no need to add an extra emphasis to it through the use of muller in Galician or donna in Italian.

Sexist use in ST

\begin{tabular}{|l|l|l|l|l|}
\hline \multicolumn{1}{|c|}{ ST } & \multicolumn{1}{c|}{ MR } & \multicolumn{1}{c|}{ TT (Galician) } & \multicolumn{1}{c|}{ SP } & \multicolumn{1}{c|}{ IT } \\
\hline $\begin{array}{l}\text { a sliding hatch } \\
\text { higher up so } \\
\text { that policemen } \\
\text { could look in } \\
(17)\end{array}$ & a policía & $\begin{array}{l}\text { os policías } \\
(28)\end{array}$ & $\begin{array}{l}\text { los policias } \\
(15)\end{array}$ & i poliziotti (19) \\
\hline
\end{tabular}

The term 'policemen' in the ST can be seen as a sexist use of language in that a more neutral form could have been used in this context, such as the police as there is no clear indication to the sex of the police. Although its sexist or non-sexist use in the ST can be debatable, more attention should be drawn to its translated version in order to assess the strategy used to deal with it. Reimóndez refused to reproduce it in the masculine form in order to avoid 
any kind of sexist bias in her text and opted for a more abstract and neutral word. Barcia's version as well as the other TT versions have all opted for a faithful representation of this term in the masculine form in order to respect the ST author's intentions. This strategy is highly criticised by Reimóndez, who claims that: "there is still a widespread belief, in the Galician context and generally, that translation must be faithful — to whom? — and that translators have to be secondary figures, invisible and quiet. That attitude is in line with traditional translation theory, which has come down to us through centuries of submission and complicity with mainstream values" (ibid.: 82).

Strategy n. $3=$ The Curious Case of Sex Change

\begin{tabular}{|c|c|c|c|c|}
\hline ST & MR & TT (Galician) & $\mathrm{SP}$ & IT \\
\hline $\begin{array}{l}\text { Then I heard } \\
\text { Toby waking } \\
\text { up, because he } \\
\text { is nocturnal } \\
\text { and I heard } \\
\text { him rustling in } \\
\text { his cage (150) }\end{array}$ & ... é nocturna & $\begin{array}{l}\text {... é nocturno } \\
\text { (163) }\end{array}$ & $\begin{array}{l}\text { es nocturno } \\
(102)\end{array}$ & $\begin{array}{l}\text {... è un animale } \\
\text { notturno (142) }\end{array}$ \\
\hline
\end{tabular}

In Galician, "rat" is translated as rata, which is a feminine noun and, from a grammatical point of view, agreements should be made in the feminine. Nevertheless, Barcia accused Reimóndez of manipulating the text on several occasions, especially in this case where she opted for a feminisation of the term. The problem is that in this example the term "rat" is not used but only its name is given, that is, Toby. This is why the best strategy would have been that of opting for an agreement in the masculine. Both the Spanish and the Italian versions find a possible good justification for their strategies in this respect. The word "rat" is feminine also in Spanish and throughout the text all the agreements are made in the feminine except in the case mentioned above for the reason that the word rat is not used in this paragraph. In the Italian version the word 'animal' is added and this strategy does not alter either the ST message or the sex of the ST "rat".

Can this be a case of appropriation of the ST? In this respect, Reimóndez's position is quite strong as she asserts that translators should not be "secondary figures, invisible and quiet [...] in line with traditional translation theory, which has come down to us through centuries of submission and complicity with mainstream values" (ibid.). Her claims become even stronger when referring to the issue of ownership which is characterised by an unequal and unfair concept of power between author and translator and she asserts that 
"any translation is an interpretation of the text, and therefore the author has no right to decide over that new text" (ibid.: 83).

\section{Ideological reading (and translation) of gender: Translating Woolf's Orlando}

The second case-study is a comparative-contrastive analysis between Woolf's Orlando (1928) and two Italian translations: Orlando, by a female translator (Alessandra Scalero), and Orlando. Un uomo? Una donna?, by a male translator (Alberto Rossatti). The aim is to examine the ideological character of these translations as well as their contribution to the literary and cultural debate on the nature and representation of femininity and, in Orlando's specific case, of androgyny. To achieve this purpose, discussion is on noteworthy remarkable passages revealing the representation of gender in translation and textual sites of ideological tension where questions about the nature and representation of femininity + masculinity (= androgyny) are at stake. In particular, this case study seeks to investigate the differences, semantic deviations and equivalences emerging from the translations of specific keywords (he-man-male; she-female-woman; sex, change, fashion) which reveal the leitmotiv of Woolf's literary work, that is, metamorphosis.

The reason why I chose to analyse Orlando is that it engages the reader at many levels. Firstly, Woolf blends genre categories (biography, fiction, and history) and parodies straightforward representations with multiscenic elements from Shakespeare to Botticelli, involving the reader as a self-conscious and active participant in the narrative process of literary hybridization. What is particularly relevant to this study is the stylistic agency of Orlando which both challenges the modernist assumptions that characters "own" the text in some progressive individual history and rejects the notion that history is packaged in neat, delimited periods thus leading to a radical break from history. Woolf's efforts to revise and re-imagine a past that had always been depicted as primarily masculine (= history) branched out into two major biographical/ historical projects. First, she frequently attempted to re-write official history so as to provide what the French feminist theorist Hélène Cixous has named "the other history" — the history not of "Great Men" but of women. Secondly, with Orlando, Woolf challenged and expanded the signification of the sex-gender paradigm, introducing the theme of "be-coming a wo+man" and revealing that she was fascinated by transvestism and trans-sexualism. Woolf's

4. This wordplay encloses the core of Woolf's Orlando: the shift from being a man to becoming a woman. 
challenge, indeed, is specifically addressed to those Victorian thinkers who had preached that "proper" masculinity and femininity were inborn and that sexuality was essentially immutable whereas sexologists brought to attention both the fluidity and the artifice of gender.

There is little information available on Alessandra Scalero. What is known is that her activity as a translator developed between 1920 and 1940. At this time, a new model of intellectual work was emerging in Italy. Despite the repression by the fascist propaganda, Italian women began to fulfil important roles as cultural mediators, for example, working as advisors or managing directors in the publishing industry and as translators. Many female translators were also actively involved in the cultural debates of that period. Alessandra Scalero was one of them. In this context, translation emerged as a kind of reaction against the conventional culture of the time by promoting the development of foreign literatures. However, at the beginning, female translators had a shadowy existence; their names, for example, were left out of the translated text. Since 1945, there has been an increasing recognition of the translator's crucial role and the legal status of translation. Alberto Rossatti translated Orlando in 1993 — sixty years after Scalero. Rossatti's translation activity, then, developed during a time (the 1980s) when translation was fully recognized both in copyright law and in contractual arrangements. Since the $80 \mathrm{~s}$, the translator's name has always been written on the title page and sometimes even next to the author's name. Therefore, Rossatti's work was carried out in a context where translation practice was no longer invisible.

I will focus here on some of the examples that I found most noteworthy when I compared the source text and its two translations.

Woolf's work has a title (Orlando) and a subtitle (A Biography). The paratextual function of the title and subtitle is, in Genette's terms, the "threshold" to the text which unveils the author's literary aims. The title Orlando has a parodic function as it mentions a "character" whose name is an intertextual references to Orlando Furioso by Ariosto, and to the Shakespearian Orlando in As You Like It. Moreover, the use of names in the titles of literary works is typical of the realistic novel, the same genre that Woolf tried to deconstruct. The subtitle has a parodic function too: apart from denoting a specific genre (biography), it refers to A (=one) biography, although, as we learn through the novel, Orlando has multiple selves and identities.

(1) ST: Orlando. A Biography

TTsca: Orlando

TTross: Orlando. È un uomo? È una donna? 
Regarding the translation of the title, we see that the two translators make different choices. In both translations, there is an important loss, which is the omission of the subtitle and its possible parodic aim. But what is to be insisted upon is the translation shift by Rossatti who adds a question to the title: $\grave{e}$ un uomo? è una donna? (Is he a man? Is she a woman?). From a gender-oriented perspective, this question can be interpreted as a deliberate intervention of the male translator, who reveals an essentialist posture when considering human subjects only in dualistic terms (man/woman, nature/culture, etc). Rossatti's translation choice misunderstands Woolf's literary proposal of creating a third gender, i.e. the androgynous (wo+man). She explicitly tells us, in the last chapter of the novel, that "whether, Orlando was most man or woman, it is difficult to say and cannot now be decided".

Rossatti's choice may also be explained as a culturally specific intervention which aims at exciting and attracting the contemporary readers' attention to gender issues.

This analysis follows with the opening of Orlando, as it immediately calls the reader's attention to the protagonist's sexual identity, starkly marked, both in the ST and the two TTs, by the masculine pronoun 'he', whose readability is immediately put into question (see example 2).

(2) ST (chapter I, 11) He - for there could be no doubt of his sex, though the fashion of the time did something to disguise it- was in the act of slicing at the head of a Moor which swung from the rafters. [...]

TT (Scalero, 7) Egli — poiché dubbio non v'era sul suo sesso, per quanto la foggia di quei tempi alquanto lo dissimulasse - stava prendendo a piattonate la testa di un moro, che dondolava appesa alle travi del soffitto. $[\ldots]$

TT (Rossatti, 55) Lui —non v'era alcun dubblio sul suo sesso, anche se un po' dissimulato dalla moda dell'epoca — era intento a vibrare fendenti contro la testa di un Moro che dondolava dal soffitto. [...]

Hence, if it is true that the first distinction we make on meeting someone is to establish the sex of a human subject (male or female?), Orlando's beginning exposes that quite openly. However, the denial of a doubt introduces a doubt, and the gender marker 'he', which serves as initial classification, putting individual into one group, is not allowed to stand without classification. The (un)certainty about "his sex" demonstrates how this most basic difference is at once linguistic and visual: He, Egli, Lui. The deviousness of this move seems to be echoed by the immediate mention of "disguise", as though sex was a matter of tricks and cover-ups, of looking like what you are not. The peculiarity of the passage is reinforced by the lack of logic in the statement on 
closer inspection. It is the ephemerality associated with fashion which acts as a decoy from the previous inconsistency. What is really striking in this first passage is the translation of the term fashion "of the time": the female translator (Scalero) translates it with foggia, a word that in Italian has two meanings or more:

1 (maniera) manner; (moda) fashion; (stile) style;

2 (aspetto) look; (forma) shape; (taglio) cut.

Scalero's lexical choice may be ideologically value-laden: it is as if she was subtly referring to both Orlando's physical appearance as/of a man and the fashion of the time in the sense of the historical period. Rossatti's lexical choice, moda, does not introduce such an ambiguity (textual/sexual).

The problem of knowing what Orlando is derives from the "fashion", which did something to disguise it. This implies that it is indeed bodily features, visually ascertainable with the removal of any distracting "disguise", which settle the question of a person's sex. But it would follow from this that putting on deceptive clothes might perhaps be sufficient to change the sex in the eyes of the beholder. Thus, despite the lexical deviation, all three terms, 'fashion', 'foggia', 'moda', anticipate Woolf's focus on cross-dressing: clothes can point to gender identity as being a cultural and social construction, as a kind of imposition dictated on the body through external elements, whereas the individual's spiritual quality is independent of sex.

As the novel proceeds, Orlando grows up and falls in love with Sasha, a Russian princess. The third example portrays Sasha, first love of the young male Orlando - who attracts him for being mysterious and ambiguous; the complex embodiment of a wo+man.

(3) ST (27-28) When a boy, for alas, a boy it must be - no woman could skate with such speed and vigour- swept almost on tiptoe past him, Orlando was ready to tear his hair with vexation that the person was of his own sex, and thus all embraces were out of the question. But the skater came closer. Legs, hands, carriage, were a boy's, but no boy ever had a mouth like that; no boy had those breasts; no boy had eyes which looked as if they had been fished from the bottom of the sea. Finally, $[\ldots]$ the unknown skater came to a standstill. [...] She was a woman.

TT (Scalero, 30) Allorchè il garzone, poiché, ahimè, era certo un garzone - quale donna avrebbe pattinato con tanta velocità, con tanto vigore? - lo sfiorò in una piroetta sulla punta del piede, Orlando stava per strapparsi i capelli dalla disperazione che si trattasse di un essere del suo medesimo sesso, e non fosse quindi il caso di parlar d'abbracci. Ma il pattinatore si avvicinava. Gambe, mani, portamento erano di un giovinetto, ma qual giovinetto ebbe mai una bocca simile' e quei seni? Qual 
giovinetto aveva occhi che parevano usciti dalla profodità del mare? In ultimo, $[\ldots]$, lo sconosciuto pattinatore si arrestò. [...] era una donna.

TT (Rossatti, p. 74) Quando il ragazzo, poiché, ahimè, era certo un ragazzo - nessuna donna sui pattini sarebbe mai stata tanto veloce $e$ potente- gli sfrecciò accanto quasi sulle punte, per poco Orlando non si strappò i capelli per la rabbia che quella persona fosse del suo stesso sesso e quindi di abbracci non se ne parlava nemmeno. Ma il pattinatore si avvicinò. Gambe, mani, portamento, erano quelli di un ragazzo, ma nessun ragazzo aveva quella bocca, quei seni [...] nessun ragazzo aveva quegli occhi che parevano pescati negli abissi del mare. Infine [...] lo sconosciuto pattinatore restò immobile. [...] Una donna.

Sasha's indeterminacy is another example of identity vacillation. It confounds the security of the sexual/textual structure in which the two sexes can be confidently distinguished by reducing its determinants to a matter of outward appearances, suggesting what may or may not be the true identity underneath. Sasha vacillates — as does Orlando- between sexes, presenting femininity as an inherently unstable position, or as if its very condition were one of putting on and taking off the identities of one sex or the other. This may be a feminist strategy of unmasking the pretentiousness of patriarchal ideas of fixed gender identities and playing up the possibilities of endless dissimulation of mobile identity. As to the translation of this passage, the Italian versions present interesting differences between them.

Whereas the male translator prefers translating the English "boy" with the common modern Italian equivalent 'ragazzo', the female translator opts for 'garzone' and 'giovinetto' making a change in the register. These terms, which belong to a classical and learned register, function as subtle gender markers in describing Sasha's identity, whose form " $(\ldots)$ combined in one the strength of a man and a woman's grace" (Woolf 1928: 98). Indeed, in Italian 'garzone' explicitly refers to a vigorous boy who usually devotes himself to carrying out some hard physical work, whereas the word 'giovinetto' alludes to a delicate child. ${ }^{5}$ In particular, the issue of the boy's strength as a peculiarity of the male nature is described by Woolf — and subtly parodied by the female translator - just when Orlando has become a woman, as described in the following passage:

(4) ST (113) [...] 'All I can [Orlando] do, once I set foot on English soil, is to pour out tea and ask my lords how they like it. D'you take sugar. D'you take cream?' And mincing out the words, she was horrified to perceive how low an opinion she was forming of the other sex, the manly, to

5. See F. Palazzi \& G. Folena. Dizionario della lingua italiana. Loescher, 2000. 
which it had once been her pride to belong [...] 'Heavens!' she thought, 'what fools they make us - what fools we are!' And here it would seem from some ambiguity in her terms that she was censuring both sexes equally, as if she belonged to neither; and, indeed, for the time being, she seemed to vacillate; she was man; she was woman; she knew the secrets, shared the weaknesses of each.

TT (Scalero, 143) "Tutto quello che mi sarà permesso, dopo che sarò sbarcata in Inghilterra, sarà di servire il tè e di chiedere ai signori ospiti come lo preferiscono. Lo volete zuccherato? Un po' di crema?" E mentre parodiava se stessa, fu colpita da orrore, avvedendosi della bassa opinione che si andava formando dell'altro sesso, quel sesso forte al quale un giorno era stato suo orgoglio appartenere [...] "Cielo! Che zimbelli fanno di noi e che sciocche siamo mai!” E qui, dall'ambiguità di alcune sue parole, si sarebbe potuto comprendere come ella censurasse entrambi i sessi, quasi non appartenesse né all'uno né all'altro; e, in questi momenti, ella pareva titubare; era un uomo; era una donna; conosceva i segreti, divideva le debolezze di entrambi.

TT (Rossatti, 166) "Tutto quello che mi sarà concesso, dopo che avrò messo piede sul suolo inglese, sarà di servire il tè e chiedere ai signori come lo desiderano. "Zucchero? Un pò di latte?" E mentre pronunciava quelle parole con affettazione, comprese con orrore il disprezzo che andava nascendo in lei per l'altro sesso, quello maschile, al quale un giorno aveva avuto l'orgoglio di appartenere. [...] "Cielo!" esclamò "Come si prendono gioco di noi...come siamo sciocche!" E qui, da una certa ambiguità delle sue parole si sarebbe potuto credere che criticasse entrambi i sessi, come se non appartenesse né all'uno né all'altro. In effetti, per ora, sembrava vacillare; era un uomo; era una donna; conosceva i segreti, condivideva le debolezze di entrambi.

The Italian speaking reader can immediately perceive the literary trope and textual strategy adopted by the female translator who opts for 'sesso forte' ('the strong sex') instead of 'sesso maschile', which is the literal equivalent for the English 'the manly sex'. At first glance, it is as if Scalero was expressing and perpetuating in terms of gender stereotypes and hierarchies (man/ woman, sterner/weaker, superior/inferior, etc.), the power relations between the sexes. My reading is quite different. I would like to suggest that Scalero's translation choice is actually challenging the conventional dichotomies she textually emphasises and deconstructs, using one of Woolf's favourite rhetorical artifice in Orlando: parody. Translation is in itself an intensely relational act as it establishes connections between text and culture, author and translator, foregrounding (their) positionality of enunciation. Translation is not a simple transfer, but the continuation of a process of meaning creation within a contingent network of text and social discourses. 
My last remark concerns the function and the translation of subject pronouns. Gender-markers are key-elements in the novel because they orient the readers towards Orlando's sex and the gender s/he takes on at different times throughout the centuries. In example 4, the subject pronouns serve to mark the fluctuation of the character's identity. However, each language has its own grammatical structure and cohesion system, each has its own set of rules. For example, in English, subject pronouns are generally set in a thematic position, whereas in Italian, they are often omitted and replaced by the inflection of the verb. In the passages concerning Orlando's metamorphosis the representation of his/her androgyny is linguistically and visually represented by the use of pronouns, as we can see in the following example:

(5) ST (Cap.III, 97) [...] He stretched himself. He rose. He stood upright in complete nakedness before us, and while the trumpets pealed Truth! Truth! Truth! We have no choice left but confess - he was a woman. [...] We may take advantage of this pause in the narrative to make certain statements. Orlando had become a woman - there is no denying it. But in every other respect, Orlando remained precisely as he had been. The change of sex, though it altered their future, did nothing whatever to alter their identity. Their faces remained, as their portraits prove, practically the same. His memory - but in future we must, for convention's sake, say 'her' for 'his', and 'she' for 'he'- her memory then, went back through all the events of her past life without encountering any obstacle. [...] The change seemed to have been accomplished painlessly and completely and in such a way that Orlando herself showed no surprise at it. Many people, taking this into account, and holding that such a change of sex is against nature, have been at great pains to prove (1) that Orlando had always been a woman, (2) that Orlando is at this same moment a man. Let biologists and psychologists determine. It is enough for us to state the simple fact; Orlando was a man till the age of thirty; when he became a woman and has remained so ever since.

TT (Scalero, 124) Si stirò le membra. Si alzò. Sostò ritto in piedi dinanzi a noi, nella sua assoluta nudità, e mentre durava ancora il tonitruare delle trombe: Verità!Verità!Verità! altro non ci rimane se non confessare la verità... Orlando era una donna. [...] Coglieremo l'occasione di questa pausa nel nostro racconto, per fare alcune constatazioni. Orlando —vano sarebbe stato negarlo- era diventato donna. Ma sotto ogni altro rapporto, Orlando rimaneva tale e quale quello di prima. Il mutamento di sesso poteva bensì alterare l'avvenire dei due Orlando, ma per me nulla affatto la loro personalità. I due visi rimasero, come lo provano i ritratti, perfettamente simili. Egli —ma d'ora d'innanzi sarà bene, per convenzione, dire "ella" invece di "egli" —ella poté dunque, nella sua memoria, risalire il corso degli eventi del suo passato, senza incontrare alcun ostacolo. [...] La metamorfosi sembra essersi compiuta senza alcun dolore, nel modo più completo, e con tanta perfezione che Orlando 
stessa non ne fu minimamente sorpresa. Numerosi sono gli scienziati i quali, nel contestar questo fatto, sostengono che un mutamento di sesso una cosa contro natura, e hanno sudato non poco per provare: 1 . Che Orlando era sempre stato una donna; 2. Che Orlando era tuttora un uomo. Lasciamo il dilemma ai biologi e agli psicologi. A noi basterà constatare il fatto nudo e crudo. era Orlando stato un uomo fino ai trent'anni; dopo di allora, diventò una donna, e tale è rimasto.

TT (Rossatti, 150-151) [...] Si stiracchiò. Si alzò. Era in piedi davanti a noi completamente nudo, e mentre le trombre proclamavano Verità!Verità!Verità! siamo costretti a confessarlo —Orlando era una donna. [...] Profitteremo di questa pausa nella narrazione per fare alcune constatazioni. Orlando era diventato donna -inutile negarlo. Ma sotto ogni altro aspetto, rimaneva lo stesso Orlando di prima. Il mutamento di sesso poteva mutare il futuro dei due Orlando, ma non certo la loro identità. I loro visi, come provano i ritratti, rimasero identici. Lui poteva —ma d'ora in avanti sarà meglio dire "lei" invece di "lui"— lei poteva dunque, nella sua memoria, risalire senza difficoltà il corso degli eventi della sua vita passata. [...] [...] La metamorfosi sembrava essere stata indolore, completa e tale che Orlando stessa non ne fu sorpresa. In considerazione di ciò, molti, sostenendo che un simile mutamento di sesso sia contro natura, si sono affannati a provare 1) che Orlando era sempre stato una donna; 2) che Orlando era tuttora un uomo. Lasciamo il dilemma ai biologi e agli psicologi. A noi basterà una sola cosa: Orlando era stato un uomo fino all'età di trent'anni, quando divenne una donna e tale è sempre rimasta.

\section{Concluding remarks}

For years, translations were considered as derivatives, copies and subordinate elements in society just like women. The intersection between gender issues and translation reveals a great deal about ideologies and their effects in translation. If a deviation from the ST is found in terms of translation strategies, then it tends to be seen as a deliberate ideological and feminist practice in the case of female translators. The question is, however, that not all women translators are feminist activists and the same translation strategies can, at times, be adopted by male translators who are not declared feminists. In fact, as we have demonstrated throughout this paper, there is no such a thing as a "feminist translation strategy" but rather it is the use of a particular practice which reflects a specific ideological strategy not necessarily associated with any feminist agenda. In particular, the outcomes of our analyses have led us to reflect on the extent to which gender representation in translation practice can be shaped by the translator's identity as a means of decoding subjectively the meaning of a text or specific transemes within a text. Our case studies 
have shown that some translation choices unveiled the ideological reading of gender as in the case of Reimóndez's strategy to use non-sexist language in the text in cases where no clear indication of the sex is given. On the one hand, as a feminist translator, she believes that language and texts do not have to comply with the male-as-norm principle and if a masculine word can be used as a gender-inclusive term, why should not a feminine term? On the other hand, however, this study has also shown that the male translator's (Barcia) choice of rendering the English term liar with a feminine gender in Galician where no clear indication about the sex of "that liar" was provided in the ST did not seem to raise any kind of objection. What these two translators did, indeed, was to adopt exactly the same strategy of blaming the other sex for something negative occurring in the text. This was achieved by manipulating the grammatical gender in the Galician TT.

Similarly, in Scalero's translation of Orlando, it is as if the female translator transgressed the principle of textual equivalence and formal correspondence throughout her translation, opting for the use of evaluative and emotional lexis maybe in order to show a certain fidelity to gender issues related to Woolf's experience as a woman and a writer. The kind of empathetic relationship that Scalero established with Woolf's text may also be read in terms of elective affinity; we can suppose that the translator has been drawn to that text as a kindred spirit and has recognized herself in it. Differently, in Rossatti's translation some lexical choices can be explained as culturally-specific interventions and market-oriented strategies as in the case of adding the subtitle è un uomo? è una donna? (Is he a man? Is she a woman?). The implication of his choice is twofold: on the one hand, it aims at exciting and attracting the contemporary readers' attention to gender issues; on the other, it neutralizes Woolf's literary proposal of representing identity vacillation by creating a third gender, i.e. the androgynous. (wo+man).

However, it is worth noting that not all forms of manipulation in translation are ideologically value-laden or due to gender differences since many translation shifts or losses are carried out merely to adhere to literary and aesthetic constraints. It should also be stressed that not all forms of non-conformity, deviation and intervention in the original text on the behalf of female translators are always cases of feminist strategies. There are, indeed, some female translation scholars such as Baker (2006) and Tymoczko (1999) who are explicitly interventionist, though they are not feminist activists, since they firmly believe that intervention is inherent in any act of translation and interpretation and this is functional to the defence of social equality and justice 
especially when translators are heavily engaged in mediating a wide range of violent political conflicts.

Finally, there is no doubt that any act of communication and language use, including translation, involves ideological and manipulative purposes and (un)fortunately translation is one of the most suitable platforms for such practices. Indeed, translation strategies tend to reflect, to a greater or lesser degree, the translator's ideological positioning that can be explicitly or implicitly expressed and propagated and it becomes observable through discourse.

\section{References}

Primary Sources

Haddon, M. (2003) The Curious Incident of the Dog in the Night-Time. London: Jonathan Cape Ltd. Translated into Galician by Moisés Barcia as O curioso incidente do can á media noite, Rinoceronte Editora, 2008. Translated into Spanish by Patricia Antón as El curioso incidente del perro a medianoche, Barcelona: Ediciones Salamandra, 2004. Translated into Italian by Paola Novarese as Lo strano caso del cane ucciso a mezzanotte, Turin: Einaudi, 2003.

Woolf, V. (1928) Orlando. A Biography. London: Penguin Books, 1993. Translated by Alessandra Scalero as Orlando, Milan: Medusa-Mondadori, 1933; and by Alberto Rossati as Orlando. Un uomo? Una donna?, Milan: Rizzoli, 1993.

\section{Secondary Sources}

BAKER, M. (2006) Translation and Conflict. A Narrative Account, London: Routledge. BRAUN, F. (1997) "Making men out of people: the MAN principle in translating genderless forms". In: Kotthoff, H. \& R. Wodak (eds.) Communicating Gender in Context. Amsterdam: John Benjamins, pp. 3-30.

Brufau Alvira, N. (2010) "Interviewing Luise von Flotow: A new state of the art". Quaderns 17. pp. 283-292.

Castro VÁzquez, O. (2009) "El género (para) traducido: pugna ideológica en la traducción y paratraducción de $O$ curioso incidente do can á media noite". Quaderns 16. pp. 251-264.

Chesterman, A. (1997) Memes of Translation. Amsterdam: John Benjamins.

HÖNIG, H. \& P. Kussmaul (1982) Strategie der Übersetzung. Ein Lehr- und Arbeitsbuch. Tübingen: Gunther Narr Verlag.

GuarRido Virlariño, X. M. (2005) "Texto e paratexto. Tradución e paratradución". Viceversa 9-10. pp. 31-39.

LEONARDI, V. (2007) Gender and Ideology in Translation: Do Women and Men Translate Differently? A Contrastive Analysis from Italian into English. Bern: Peter Lang. 
MASSARDIER-KenNeY, F. (1997) "Towards a Redefinition of Feminist Translation Practice". The Translator 3(1). pp. 55-69.

MiLls, S. (2003) "Third wave linguistic feminism and the analysis of sexism". Discourse Analysis Online 2:1. http://extra.shu.ac.uk/daol/articles/open/2003/001/ mills2003001-paper.html. (Accesed on May 20, 2010)

Mills, S. (2008) Language and Sexism. Cambridge: Cambridge University Press.

REIMÓNDEZ, M. (2009) "The curious incident of feminist translation in Galicia: court cases, lies and gendern@tions”. Journal of Contemporary Galician Studies, Issue A. pp. 68-89.

The Telegraph, Curious case of the sex changes, $5^{\text {th }}$ April 2008. http://www. telegraph.co.uk/news/worldnews/1584020/Curious-case-of-the-sex-changes. html. (Accessed on June 26, 2010)

TymoczKo, M. (1999) Translation in a Postcolonial Context: Early Irish Literature in English Translation. Manchester: St. Jerome.

VON Flotow, L. (1991) "Feminist translation: Context, practices, theories". TTR 4(2). pp. 69-84.

VON Flotow, L. (1997) Translation and Gender: Translating in the 'Era of Feminism'. Manchester: St Jerome.

VON Flotow, L. (1998) "Dis-unity and diversity". In: Bowker, L.; M. Cronin; D. Kenny \& J. Pearson (eds.) 1998. Unity in Diversity? Manchester: St Jerome, pp. 3-13. 